\title{
Effect of Copper on Sunflower (Helianthus annus L.)
}

\author{
Muhammad Faraz Ali*, Muhammad Jamil, Kamran Ahmad, Muhammad Abu Bakar, Mehwish, Samra Abbas, \\ Mudassar Nadeem, Tehmina Batool
}

\author{
Department of Botany, University of Agriculture, Faisalabad \\ DOI: 10.29322/IJSRP.10.02.2020.p9829 \\ http://dx.doi.org/10.29322/IJSRP.10.02.2020.p9829
}

\begin{abstract}
The effects of different concentrations of copper sulphate on the growth of and the accumulation of $\mathrm{Cu}^{+2}$ by root, shoot, chlorophyll content and leaf growth of sunflower (Helianthus annus L.) were examined in this study. The purpose of our experiments was to consider sensitivity of two sunflower hybrid cultivars (FH626 and FH674) to copper ions on the ground of physiological characteristics amount of assimilatory pigment, and shooth length to show possible resistance mechanisms of this plant to copper ions. The experiment was conducted in Completely Randomized Fashion with three replications per treatment and five plants per replication. Tested cultivars varied according to the tested parameters, such as shooth length, relatively high rate of tolerance. Although no significant visual symptoms of toxic effect of metal were markedly noticeable, a decrease in the content of dry basis in the roots was seen in comparison with the control of two tested cultivars treated by Cu. FH626 \& FH674 tend to be the most resistant or tolerant hybrid cultivars to $\mathrm{Cu}$ toxicity from the point of view of evaluation of morphological parameters of the cultivars.
\end{abstract}

Index Terms- Helianthus annus, Copper sulphate,Carotenoids, Chlorophylls, Shoot length

\section{INTRODUCTION}

$\mathrm{C}$ opper is an essential heavy metal for higher plants and algae, particularly for photosynthesis (Ouzounidou et al., 1992). Cu is a constituent of primary electron donor in photosystem I, the copper protein plastocyanin. Because $\mathrm{Cu}$ can readily gain and lose an electron, it is a cofactor of oxidases, mono- and di oxygenase (e.g. amine oxidase, ammonia monoxidase, ceruloplasmin, Iysyl oxidase) and of enzymes involved in the elimination of superoxide radicals (e.g. Superoxide dismutase and ascorbate oxidase).

Several enzymes contain in, such as carbonic anhydrase, alcoholdehydrogenase, superoxide dismutase and RNA polymerase 1 is required to maintain the integrity of ribosome. It takes part in the formation of carbohydrates andcatalyses the oxidation processes in plants. Copper $(\mathrm{Cu})$ loading of agricultural soils may originate from the application of sewage sludge or fungicidal sprays.

Although $\mathrm{Cu}$ is an essential element for plant growth (Arnon and Stout 1939), its accumulation in soils may be toxic to biota, such as plants (Baryla et al., 2000) and microorganisms (Dumestre et al., 1999), and at toxic concentrations it interferes with numerous physiological processes (Fernandes and Henriques 1991).
It is also known to damage the cell membranes by binding to sulphydryl groups of membrane proteins and inducing lipid peroxidation (De Vos et al., 1989, 1992). Cu is extremely toxic and can catalyse the formation of active oxygen species in the cell through Haber-Weiss reaction (Kurepa et al., 1997).Since oxidative stress is produced in plants exposed to high metal concentrations, the implication of some antioxidant enzymes may complement the role of phyto-chelatins in the cellular response to metal toxicity (Mazhoudi et al., 1997).Copper is an essential micronutrient for normal plant metabolism (Sharma and Agrawal, 2005).

Copper is involved in several physiological processes such as the photosynthetic and respiratory electron transport chains (Van Assche and Clijters, 1990)and as a cofactor or as a part of the prosthetic group of many key enzymes involved in different metabolic pathways, including ATP synthesis (Horrisonet al., 1999).Despite its physiological importance, an increase in $\mathrm{Cu}$ contents threatens plant health because it interacts with several enzymesand disturbs membrane permeability and electron transport in chloroplasts. Its toxicity to plants is well documented (Ouzounidou et al., 1998).

Decrease of chlorophyll content in plants after exposure to copper is frequently reported in the literature (Singh et al., 2007). (Prasad et al. 2001) attributed $\mathrm{Cu}$-induced chlorophyll content decrease to $\mathrm{Cu}$ modification of chlorophyll degradation. For all plants, quality of irrigation water is greatly important. Sunflower is an important field crop, cultivation of which depends on the quality of the soil and water, beside some other factors. One of the important factors which spoil the quality of water and soil are heavy metals.

In this study, the effects of the copper on the content of chlorophyll $(\mathrm{a}+\mathrm{b})$, proline, protein and abscisic acid in sunflower seedlings were investigated. It was determined how some physiological and biochemical parameters were changed due to concentration of the copper.

\section{MATERIALS AND METHODS}

\section{Plant Material and Sowing:}

Seeds of two sunflower hybridsi.e. FH626 and FH674 were obtained from Ayub Agriculture Research Institute and weresown in completely randomized design (CRD) to analyze the influence of copper stress on their growth, physiology and metabolism.There were three replications per treatment with five plants per replication. 


\section{CU TREATMENTS:}

Twoweeks old plants were treated with threeconcentrations Control Series $\left(\mathrm{T}_{0}\right)=$ distilled water

Treatment $1\left(\mathrm{~T}_{1}\right)=20 \mathrm{mM} \mathrm{CuSO}_{4}$

Treatment $2\left(\mathrm{~T}_{2}\right)=40 \mathrm{mM} \mathrm{CuSO}_{4}$

\section{PARAMETERS RECORDED:}

Morphological parameters such as shoot length, root length, shoot fresh weight and root freshweightwere recorded according to Shafiq (2019).To estimate photosynthetic pigments i.e.chlorophyll a, chlorophyll b, and carotenoids, plant materials (leaves) were harvested from the greenhouse and $0.1 \mathrm{~g}$ was placed in $8 \mathrm{ml}$ of $80 \%$ acetone for 7 days under dark conditions in the refrigerator. After 7 days absorbances were taken with UV/VIS spectrophotometer at 663, 645, and $480 \mathrm{~nm}$ (Skanlt software 3.2 for Multiskan Co., Thermo Fisher Scientific, Waltham, MA, USA). Chlorophyll content was estimated according to Arnonand Stout (1949) and carotenoid content according to Lichtenthaler(1987). The fresh leaves from the three treatments were cut and taken in ice-water. The photosynthetic pigments (chlorophyll a, b and carotenoids) were determined according to following formulas:

Chl.a $(\mathrm{mg} / \mathrm{g})=[12.7(\mathrm{OD} 663)-2.69(\mathrm{OD} 645) \times \mathrm{V} / 1000]_{\mathrm{x}} \mathrm{W}$

Chl.b $(\mathrm{mg} / \mathrm{g})=[22.9(\mathrm{OD} 645)-4.69(\mathrm{OD} 663) \times \mathrm{V} / 1000] \times \mathrm{W}$

Carotenoids $(\mathrm{mg} / \mathrm{g})=\underline{\mathrm{OD} 480+0.114(\mathrm{OD} 663)-0.638(\mathrm{OD} 645)} \mathrm{x}$ 100

2500

\section{HARVESTING:}

The plants were harvested after two months of the germination date.Root and shoot fresh weights were taken at electrical balance in grams. Similarly, the root and shoot lengths were measured in $\mathrm{cm}$ with the help of scale. The Plants were placed in oven for 4 days at $75^{\circ} \mathrm{C}$ for observing the dry weight. The dry weight of roots and shoots separately calculated.

\section{DATA ANALYSIS:}

Differences among treatments were analyzed by one-way ANOVA, taking $\mathrm{P}<0.05$ as significant according to Tukey's multiple range test.

\section{RESULTS AND DISCUSSION}

The present study indicated that $\mathrm{Cu}$ stress reduced the growth of roots, stems and leaves of sunflower plants.

\section{Shoot length}

Significant decrease in shoot length was recorded in T1 while an increase in shoot length was recorded in T2 of both genotypes. The plants of FH-626 and FH-674 when treated with $20 \mathrm{mM} \mathrm{CuSO}_{4}$ showed a significant decrease in shoot length i.e. 79.5 and 105.5 respectively as compared to control. The plants of FH-626 and FH-674 when treated with 40mM CuSO4 showed an increase in the shoot length i.e. 107.66 and 103.83 respectively as compared to control (Fig. 1).

Table -1: Effect of Copper on Shoot Length $(\mathrm{cm})$ of Sunflower.

\begin{tabular}{|l|l|l|}
\hline Treatment & Variety FH 626 & Variety FH 674 \\
\hline Distilled water (T0) & 98.83 & 126 \\
\hline $20 \mathrm{mM} \mathrm{CuSO}_{4}(\mathrm{~T} 1)$ & 79.5 & 105.5 \\
\hline $40 \mathrm{mM} \mathrm{CuSO}_{4}(\mathrm{~T} 2)$ & 107.66 & 103.83 \\
\hline
\end{tabular}

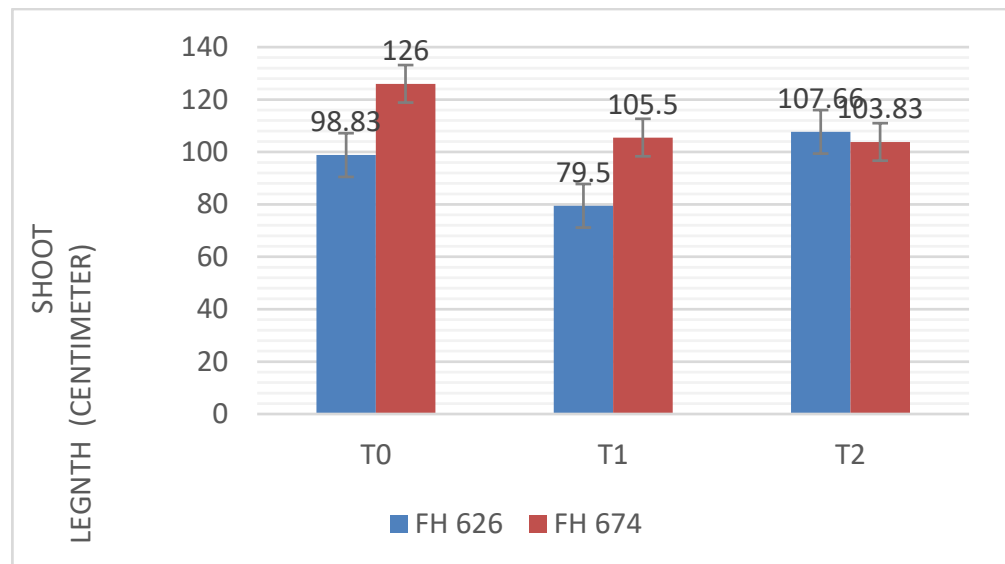

Fig. 1. Effect of Copper on Shoot Length (cm) of Sunflower

\section{Chlorophyll a}

Significant decrease in chlorophyll a content was recorded in $\mathrm{T} 1$ while an increase was recorded in $\mathrm{T} 2$ of both genotypes. The plants of FH-626 and FH-674 when treated with $20 \mathrm{mM} \mathrm{CuSO} 4$ showed a significant decrease in chlorophyll a i.e. 0.0198 and 0.0194 respectively as compared to control.

Table 2: Effect of Copper on Chlorophyll.a (mg/g) of Sunflower.

\begin{tabular}{|l|l|l|}
\hline Treatment & Variety FH 626 & Variety FH 674 \\
\hline Distilled water (T0) & 0.0144 & 0.0753 \\
\hline $20 \mathrm{mM} \mathrm{CuSO}(\mathrm{T} 1)$ & 0.0198 & 0.0194 \\
\hline $40 \mathrm{mM} \mathrm{CuSO}_{4}(\mathrm{~T} 2)$ & 0.0252 & 0.0193 \\
\hline
\end{tabular}

The plants of FH-626 and FH-674 when treated with $40 \mathrm{mM}$ $\mathrm{CuSO} 4$ showed an increase in chlorophyll a i.e. 0.0252 and 0.0193 respectively as compared to control (Fig. 2). 


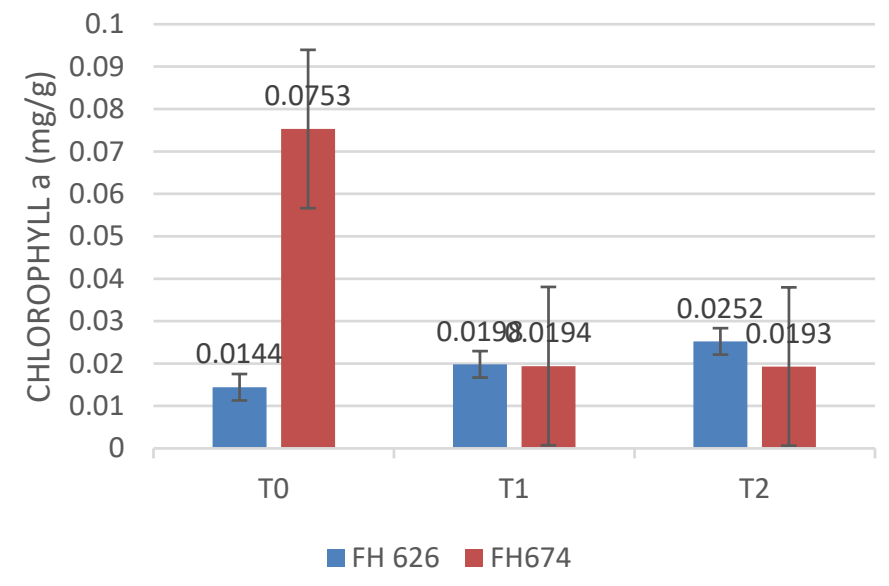

Fig. 2. Effect of Copper on Chlorophyll.a (mg/g) of Sunflower

\section{Chlorophyll b}

Significant decrease in chlorophyll b content was recorded in $\mathrm{T} 1$ while an increase was recorded in $\mathrm{T} 2$ of both genotypes. The plants of FH-626 and FH-674 when treated with $20 \mathrm{mM} \mathrm{CuSO}_{4}$ showed a significant decrease in chlorophyll b i.e. 0.0101 and 0.012 respectively as compared to control.

Table -3: Effect of Copper on Chlorophyll.b (mg/g) of Sunflower.

\begin{tabular}{|l|l|l|}
\hline Treatment & Variety FH 626 & Variety FH 674 \\
\hline Distilled water & 0.00122 & 0.0325 \\
\hline $20 \mathrm{mM} \mathrm{CuSO}_{4}$ & 0.01010 & 0.012 \\
\hline $40 \mathrm{mM} \mathrm{CuSO}_{4}$ & 0.0118 & 0.0132 \\
\hline
\end{tabular}

The plants of FH-626 and FH-674 when treated with $40 \mathrm{mM}$ $\mathrm{CuSO} 4$ showed an increase in chlorophyll b i.e. 0.0118 and 0.0812 respectively as compared to control (Fig. 3).

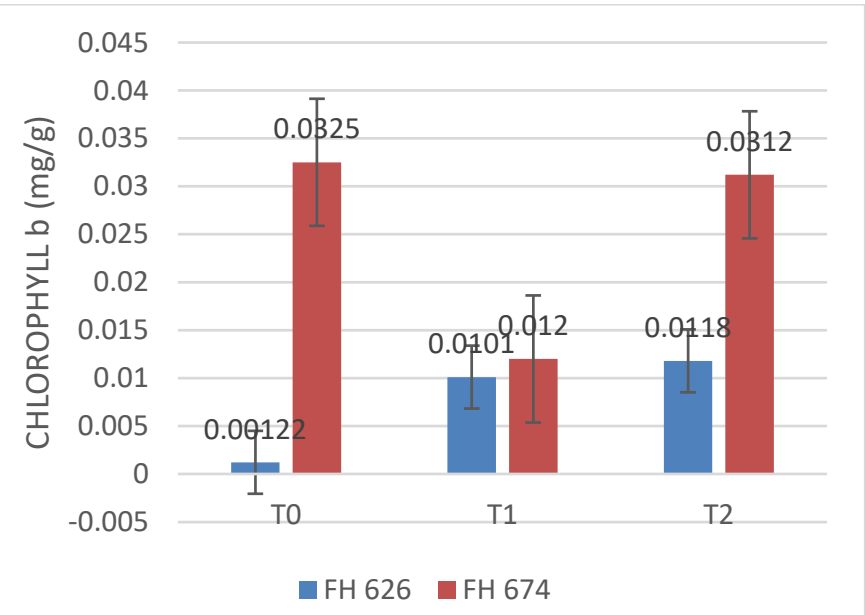

Fig. 3. Effect of Copper on Chlorophyll.b (mg/g) of Sunflower

\section{Carotenoids}

Significant decrease in carotenoids was recorded in T1 while an increase was recorded in T2 of both genotypes. The plants of FH-626 and FH-674 when treated with $20 \mathrm{mM} \mathrm{CuSO}_{4}$ showed a significant decrease in carotenoids i.e. 0.421 and 0.586 respectively as compared to control.

\section{Table -4: Effect of Copper on Carotenoids (mg/g) of Sunflower.}

\begin{tabular}{|l|l|l|}
\hline Treatment & Variety FH 626 & Variety FH 674 \\
\hline Distilled water & 0.601 & 1.087 \\
\hline $20 \mathrm{mM} \mathrm{CuSO}_{4}$ & 0.421 & 0.586 \\
\hline $40 \mathrm{mM} \mathrm{CuSO}_{4}$ & 0.613 & 0.436 \\
\hline
\end{tabular}

The plants of FH-626 and FH-674 when treated with $40 \mathrm{mM}$ $\mathrm{CuSO} 4$ showed an increase in carotenoids i.e. 0.613 and 0.436 respectively as compared to control (Fig. 4).

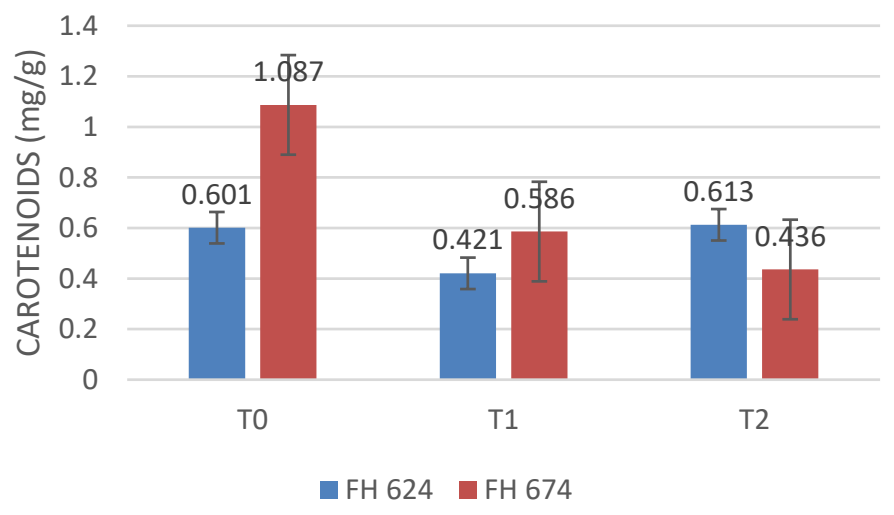

Fig.4. Effect of Copper on Carotenoids (mg/g) of Sunflower

\section{CONCLUSION}

Many aspects of the copper toxicity on the plants are clarified, however results of several physiological and biochemical analysis are controversial. At the same time, high variability of plant reaction to the heavy metal ions depending up the genotypes complicates unambiguity of the conclusions. Deeper biochemical and molecular-biological analysis can contribute to revealing of other possible mechanisms of sunflower resistance to copper ions or other heavy metals.

\section{ACKNOWLEDGEMENT}

I am thankful to my supervisor Dr. Sajid Aqeel , Assistant Professor, University of Agriculture, Faisalabad. He helped me in data collection and laboratory analysis also in writing of my research report. I am also thankful to my research group especially Muhammad Jamil, Kamran Ahmad, Muhammad Abu bakar, Mehwish, Samra Abbas, Mudassar Nadeem, Musarwir Hussain.

\section{REFERENCES}

[1] Arnon DI. and Stout PR. 1939. The essentiality of certain elements in minute quantity for plants with Speciareference to copper. Plant Physiol 14,371-375

[2] Baryla A, Laborde C., Montillet JL., Trianaphylides C., Chagvardieff P. 2000. Evaluation of lipid peroxidation as a toxicity bioassay for plants exposed to copper. Environ. Pollut 109,131-135. 
[3] De Vos CHR., Vonk MJ. Schat H. 1992. Glutathionedepletion due to copper induced phytocheationsynthesiscauses oxidative stress in Silenecucubalus. PlantPhysiol 98,853-858.

[4] Dumestre A., Sauve S., McBride M., Baveye P., Berthelin J. 1999. Copper speciation and microbial activity in long-term contaminated soils. Arch Environ. Contam.Toxicol 36,124-131.

[5] Fernandes JC. and Henriques FS. 1991. Biochemical, physiological and structural effects of excess copper in plants. Bot. Rev 57,246-273.

[6] Horrison, M.D., C.E. Jones and C.T. Domeron 1999. Copper chaperones function structure and copper-binding properties. J. BIC 4, 145-153.

[7] Kurepa J., Van Montagu M., Inze D. 1997. Expression ofsodCp and sodB genes in Nicotiana Tabacum: Effect of light and copper excess. Exp. Bot 48,2007-2014.

[8] Lichtenthaler, H.K. 1987.Chlorophylls and Carotenoids: Pigments of Photosynthetic Biomembranes. Methods in Enzymology 148, 350-382.

[9] Mazhoudi S., chaoui A., Ghorbal M., El Ferjani E. 1997. Response of antioxidative enzymes to excess copperin tomato (Lycopersicumesculentum Mill). Plant Sci 127,129-137.

[10] Ouzounidou, G., E.P. Eleftheriou and S. Karataga. 1992. Ecophysiological and ultrastructural effects of copper in Thlaspiochroleucum (Cruciferae). Can. Bot 70, 947-957.

[11] Prasad, M.N.V., P. Malee, A. Waloszek, M. Bajko and K. Strzalka. 2001. Physiological responses of Lemnatrisulca L. (duckweed) to cadmium and copper bioaccumulation. Plant Sci 161,881-889.

[12] Shafiq, S., Adeel, M., Raza, H., Iqbal, R., Ahmad, Z., Naeem, M., Sheraz, M., Ahmed, U. and Azmi,U.R. 2019. Effects of Foliar Application of Selenium in Maize (Zea Mays L.) under Cadmium Toxicity. Biological Forum -An International Journal 11, 27-37.
[13] Sharma, R.K. and Agrawal, M. 2005 Biological Effects of Heavy Metals: An Overview. Journal of Environmental Biology 26, 301-313.

[14] Singh, Dharam, K. Nath and Y.K. Sharma 2007. Response sunflower seed germination and seedling growth under copper stress. J. Environ. Biol 28,409-414.

[15] Van Assche, F. and Clijsters, H. 1990. Effects of metals on enzyme activity in plants. J. Plant, Cell \& Environment 13,195-206.

\section{AUTHORS}

First Author: Muhammad Faraz Ali*, M.Phil Botany, Department of Botany, University of Agriculture, Faisalabad, Pakistan,wwwmfa313@gmail.com

First Corresponding Author: Muhammad Jamil, M.Phil Botany, Department of Botany, University of Agriculture, Faisalabad, Pakistan, awanmuhammadjamil@gmail.com

Second Corresponding Author: Kamran ahmad, M.phil Botany, Department of Botany, University of Agriculture, Faisalabad, Pakistan, kamranzahoor9887@gmail.com

Third Corresponding Author: Tehmina Batool, M.phil Botany, Department of Botany, University of Agriculture, Faisalabad, Pakistan. 